\title{
Effect of Heat or 1-Methylcyclopropene on Antioxidative Enzyme Activities and Antioxidants in Apples in Relation to Superficial Scald Development
}

\author{
Zohar Shaham, Amnon Lers, and Susan Lurie ${ }^{1}$ \\ Department of Postharvest Science, Agricultural Research Organization, P.O.B. 6, Bet Dagan 50250, Israel
}

\begin{abstract}
AdDitional INDEX words. $\alpha$-farnesene, conjugated tienols, ascorbate peroxidase, catalase, peroxidase, superoxide dismutate, phenols, Malus sylvestris var. domestica

Abstract. 'Granny Smith' apples [Malus sylvestris (L.) Mill. var. domestica (Borkh.) Mansf.] were harvested in two seasons and stored at $0^{\circ} \mathrm{C}$ air storage with no pretreatment (control), after heating for $4 \mathrm{~d}$ at $38^{\circ} \mathrm{C}$, or after treating for 16 hours at $20^{\circ} \mathrm{C}$ with $1 \mu \mathrm{L} \cdot \mathrm{L}^{-1} 1$-methylcyclopropene (1-MCP). The effects of the two treatments on superficial scald development were consistent over both seasons. Scald began to appear after 8 weeks in control fruit, after 16 weeks in heated fruit but not on 1-MCP treated fruit. $\alpha$-Farnesene accumulation and oxidation were slower in the skin of heated than in control fruit, and almost entirely absent in 1-MCP treated fruit. The activities of five antioxidant enzymes, ascorbate peroxidase, catalase, glutathione reductase, peroxidase and superoxide dismutate, were measured at two-week intervals in the apple peel, quantitatively as total activity and qualitatively by isozyme analysis. Enzyme activities either increased or remained stable during 16 weeks of storage, except for superoxide dismutase activity, which decreased. Ascorbate oxidase activity was higher in heated than control apples and there was an additional peroxidase isozyme present in activity gels. The activities of antioxidant enzymes were lower in 1-MCP treated fruit except for catalase during the first month of storage. Lipid soluble antioxidant activity was higher in 1-MCP treated fruit than the fruit of the other treatments, and water soluble antioxidant activity was higher in both treatments than in control fruit during the time that scald was developing in control apples. Both free and total phenol contents in the peel fluctuated during storage but no consistent trend was detected. The differences in enzyme activity and antioxidant content of the peel of 1-MCP and heated apples may play a role in preventing or delaying the appearance of superficial scald.
\end{abstract}

It is widely accepted that synthesis and oxidation of the sesquiterpene $\alpha$-farnesene play a central role in development of superficial scald, a physiological storage disorder of apples and pears (Anet, 1972a, 1972b; Huelin and Coggiola, 1968; Huelin and Murray, 1966; Ingle and D'Souza, 1989). Accumulation of high levels of conjugated trienols, the oxidation products of $\alpha$ farnesene, in the fruit epidermis is closely correlated with the subsequent appearance of scald symptoms, whereas high levels of $\alpha$-farnesene itself are less well correlated with scald (Anet, 1972b; Huelin and Coggiola, 1968, 1970a). This may be in part attributed to the fact that during low temperature storage $\alpha$-farnesene content peaks and then declines before the disorder is manifested (Huelin and Coggiola, 1968; Whitaker et al., 1997).

The longstanding hypothesis of the mechanism of scald development maintains that it is the oxidation products that are toxic to fruit tissues, possibly through initiation of free-radical chain reactions, and thus, any treatment that limits $\alpha$-farnesene oxidation will reduce scald incidence and severity (Anet, 1972a, 1972b; Huelin and Coggiola, 1970a). Based on this hypothesis, application of the antioxidants diphenylamine and ethoxyquin is used commercially to control scald.

Superficial scald development is consistent with a chilling injury caused by the adverse effects of oxidative stress that occurs with prolonged storage at low temperatures (Du and Bramlage, 1995; Rao et al., 1998; Shewfelt and Purvis, 1995; Watkins et al., 1995). Huelin and Coggiola (1970b) and Anet (1972a) first proposed that scald susceptibility or resistance in different apple cultivars is, at least in part, determined by the efficiency of their natural antioxidant defenses. Anet (1974) subsequently examined

Received for publication 25 Nov. 2002. Accepted for publication 21 Apr. 2003. This research was supported by Research Grant No. US 3165-99R from BARD, the United States-Israel Binational Agricultural Research and Development Fund.

1To whom reprint requests should be addressed; e-mail zeslov@unetvision.net.il. the levels of endogenous lipophilic antioxidants in the cuticles of 16 apple cultivars and found a positive correlation between scald resistance and the presence of antioxidant levels sufficient to curtail $\alpha$-farnesene oxidation during storage. Meir and Bramlage (1988) also showed a negative correlation between scald susceptibility and high levels of unidentified lipophilic antioxidants (with an absorbance maximum at $200 \mathrm{~nm}$ ) in the cuticle of 'Cortland' apples. More recent investigations have compared the accumulation of peroxides and lipid peroxidation products with activities of enzymes that detoxify active oxygen species in peel tissue of scald-susceptible and scald-resistant apple fruit stored in air (Du and Bramlage, 1994; Rao et al., 1998). Du and Bramlage $(1994,1995)$ compared cultivars with a wide variation in scald susceptibility and found no marked changes in peroxidation or in activities of antioxidative defense enzymes during storage which could be related to scald development. In contrast, Rao et al. (1998) found a close correlation between increasing amounts of $\mathrm{H}_{2} \mathrm{O}_{2}$ and lipid peroxidation products, declining peroxidase and catalase activities, and the occurrence and severity of scald in fruit of susceptible and resistant 'White Angel' $x$ 'Rome Beauty' hybrid selections.

In the current study, we have examined a scald susceptible cultivar, 'Granny Smith', and given two treatments to inhibit the development of superficial scald: a prestorage heat treatment (Lurie et al., 1990) and treatment with 1-methylcyclopropene (Fan et al., 1999; Watkins et al., 2000). We hypothesize that treatments which inhibit development of superficial scald act by enhancing or maintaining the antioxidant capacity of the fruit tissue, thereby limiting the oxidation of $\alpha$-farnesene. In the present study, the effects of the aformentioned two treatments on scald development, and the activities of five antioxidative enzymes (measured both as activity in fruit peel extracts and as isozymes in activity gels) were assessed. In addition, water soluble and lipid soluble 
antioxidants, and concentrations of total and soluble phenols in the peel tissue were determined. $\alpha$-Farnesene accumulation and oxidation were measured to examine the relationship between their accumulation, the antioxidative activities and compounds, and scald development.

\section{Materials and Methods}

Plant material and experimental Procedure. Apples (Malus sylvestris (L.) Mill. var. domestica (Borkh.) Mansf. cv. Granny Smith) were harvested from a commercial orchard in the Jerusalem hills in early October (2000 and 2001). Fruit starch content at the time of harvest was between 2 and 3 , based on the Cornell chart where $1=$ full starch and $8=$ no starch (Blanpied and Silsby, 1992). The apples were sorted for uniformity and freedom from blemishes and then divided into three lots of 500 fruit each. One lot was placed into $0^{\circ} \mathrm{C}$ storage (control), the second heated for 4 $\mathrm{d}$ at $38{ }^{\circ} \mathrm{C}$ and then placed in $0{ }^{\circ} \mathrm{C}$ storage, the third treated $18 \mathrm{~h}$ at $20^{\circ} \mathrm{C}$ with $1 \mu \mathrm{L} \cdot \mathrm{L}^{-1} 1$-methylcyclopropene (1-MCP) and then placed in $0{ }^{\circ} \mathrm{C}$ storage. Batches of fruit were removed every 2 weeks for evaluation as described below. Fruit were treated with 1 -MCP in a $0.74-\mathrm{m}^{3}$ plastic container which could be sealed. The fruit were placed in the container in plastic field boxes, $1.04 \mathrm{~g}$ of the formulated 1-MCP product (SmartFresh from Rohm and Haas Company, Rome, Italy) of $0.14 \%$ a.i was dissolved in 20 $\mathrm{mL}$ of $40{ }^{\circ} \mathrm{C}$ water in a closed test tube. This was placed in the container with the apples, the test tube opened and the container was sealed for $18 \mathrm{~h}$.

At each sampling time, peel discs were taken from 10 fruit from each treatment for measurement of $\alpha$-farnesene and conjugated trienols (described below). Additional peel samples were frozen in liquid nitrogen and stored at $-80{ }^{\circ} \mathrm{C}$ for subsequent determination of phenols, lipid-soluble and water-soluble antioxidants. A final peel sample was ground in buffer, centrifuged, and the supernatant stored at $-80{ }^{\circ} \mathrm{C}$ for analysis of antioxidant enzyme activity (described below). At 2-week intervals, 30 fruit from each treatment were held 1 week at $20^{\circ} \mathrm{C}$ and then evaluated for superficial scald, which appeared as a brown discoloration of the peel. Superficial scald was determined as a percentage of the fruit which had this brown discoloration, no matter how much of the peel surface was affected.

ANALYSIS OF $\alpha$-FARNESENE AND CONJUGATED TRIENOLS. Five 1 - $\mathrm{cm}$ discs were removed from a strip of peel taken from the equatorial portion of each apple (10 apples total). These were placed in test tubes containing $5 \mathrm{~mL}$ hexane for $10 \mathrm{~min}$. The solutions were agitated, filtered and then absorbance read at 232, 258, 281, and $290 \mathrm{~nm}$. Content of $\alpha$-farnesene and conjugated trienols per $\mathrm{cm}^{2}$ of apple peel was calculated using extinction coefficients of 41,000 for $\alpha$-farnesene and 38,000 for conjugated trienols.

Phenol determination and antioxidant activity. One gram of frozen peel was extracted in $15 \mathrm{~mL}$ of $1.2 \mathrm{M} \mathrm{HCl}$ in $50 \%$ methanol for total phenols and in 50\% methanol alone for soluble phenols according to the method of Vinson et al. (2001). The phenol concentration was determined using Folin and Ciocalteu's phenol reagent (F 9252, Sigma, St. Lous, Mo.) with catechin as a standard.

Water soluble antioxidants were determined by measuring the iron reducing capacity of peel extracts according to Meir et al. (1995). One gram of frozen peel was ground in $15 \mathrm{~mL}$ of $0.2 \mathrm{M}$ Na-acetate buffer (pH3.5) filtered, centrifuged and the supernatant used for the reaction. Lipid soluble antioxidants were measured in a hexane extract of apple peel using 2,2 diphenyl-1-picryl
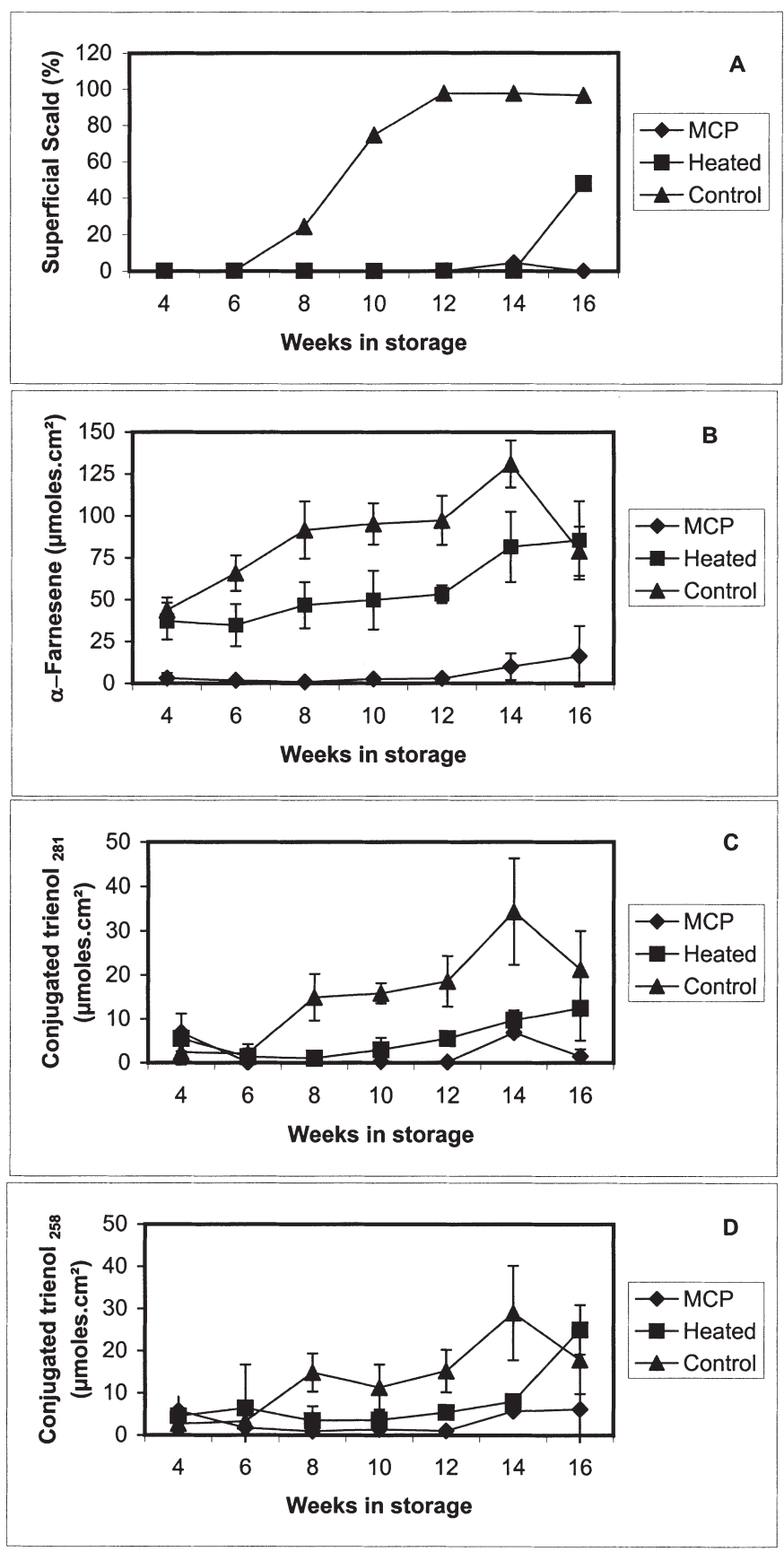

Fig. 1. Superficial scald development, levels of $\alpha$-farnesene, and conjugated trienols in 'Granny Smith' apples during 16 weeks of air storage at $0{ }^{\circ} \mathrm{C}$. Apples were either untreated (control), heated for $4 \mathrm{~d}$ at $38^{\circ} \mathrm{C}$ before storage, or treated for $16 \mathrm{~h}$ with $1 \mu \mathrm{L} \cdot \mathrm{L}^{-1} 1$-MCP. (A) Scald levels after removal from storage and holding for $7 \mathrm{~d}$ at $20^{\circ} \mathrm{C},(\mathbf{B}) \alpha$-farnesene, (C) conjugated trienol ${ }_{281}$, (D) conjugated trienol ${ }_{258}$ at removal from storage every 2 weeks. Standard deviation is indicated.

hydrazyl (DPPH) as a free radical generator (Brand-Williams et al., 1995).

ENZYME EXTRACTION AND ASSAY. Ten grams of fresh peel were ground in liquid $\mathrm{N}_{2}$ in a mortar and pestle. The frozen powder was blended in $50 \mathrm{~mL}$ of $0.2 \mathrm{M}$ phosphate buffer (pH 7.8) $2 \mathrm{~mm}$ EDTA, $0.1 \mathrm{mM}$ PMSF, and 1\% PVP $(40,000 \mathrm{kDa})$. The extract was filtered and centrifuged for $20 \mathrm{~min}$ at $4{ }^{\circ} \mathrm{C}$ at $12,000 \mathrm{~g}_{\mathrm{n}}$. The supernatant was collected, protein content determined by Coomassie blue (protein kit catalog number 500-0006; BioRad, Munich, Germany) and aliquots frozen at $-80^{\circ} \mathrm{C}$. For ascorbate 
peroxidase (APX) activity $5 \mathrm{~mm}$ ascorbic acid was included in the grinding medium.

For in vitro enzyme activity assays, the protein in the reaction mixtures was adjusted to a concentration of $1 \mu \mathrm{g} \cdot \mu \mathrm{L}^{-1}$. APX and superoxide dismutase (SOD) were assayed according to Rao et al. (1996). Catalase (CAT) was assayed by measuring the decomposition of $\mathrm{H}_{2} \mathrm{O}_{2}$ as a decrease in absorbance at $240 \mathrm{~nm}$. The reaction was assayed in $0.1 \mathrm{M}$ phosphate buffer, $\mathrm{pH} 6.8,30 \mathrm{~mm}$ $\mathrm{H}_{2} \mathrm{O}_{2}$. Glutathione reductase (GR) was determined according to Ito et al. (1993). Peroxidase (POD) was assayed in $0.1 \mathrm{~m}$ phosphate buffer ( $\mathrm{pH}$ 6.8), $30 \mathrm{~mm} \mathrm{H}_{2} \mathrm{O}_{2}, 20 \mathrm{~mm}$ guiacol by measuring the increase in absorbance at $470 \mathrm{~nm}$.

For activity gels $8 \%$ polyacrylamide gels without SDS were prepared and run at $4{ }^{\circ} \mathrm{C}$ for $4 \mathrm{~h}$. Protein preparations used for activity assay were also used for the activity gels, but the concentrations were adjusted so as to load at least $30 \mu \mathrm{g}$ of protein onto each gel lane. The activity gels were prepared and visualized according to methods described in Anderson et al. (1995).

Statistical analysis. Superficial scald, $\alpha$-farnesene and conjugated trienols determinations are combined results from experiments performed during two seasons. The remaining analyses are for the second season. For all biochemical measurements, three replicates of each treatment were prepared, and the assays for each replicate were carried out in triplicate. The results were subjected to ANOVA using Excel and comparisons among treatments at each time of sampling were made using Bonferroni's corrected $t$ test.

\section{Results}

SCAld, $\alpha$-FARneSENE, AND CONJUGated TRIENOLS. By week 8 of storage, $25 \%$ of control apples had slight scald symptoms, while apples from heated and 1-MCP treatments were scald free (Fig. 1A). By week 12 all of the control apples had developed scald. Heated apples were scald free until week 16, whereas 1MCP treated apples developed no scald during the duration of the experiment.

$\alpha$-Farnesene levels increased steadily in control apples until week 14, and then declined sharply (Fig. 1B). Levels in heated apples increased at a slower rate and remained lower than in control apples until week 16. 1-MCP treated apples had very low levels of $\alpha$-farnesene throughout the experiment. Similar patterns were seen for the two conjugated trienols, one with absorbance at $290 \mathrm{~nm}$ and the second at $258 \mathrm{~nm}$ (Fig. 1C and D). Control fruit had high levels of these compounds at 8 weeks (when scald first appeared), while in heated apples levels reached control levels only week 16. In 1-MCP treated apples conjugated trienol levels began to increase slowly only after 12 weeks.

Antioxidant ENZYMes. Enzyme activities were monitored every 2 weeks using both total activity and isozymes in activity gel assays. APX activity was stable during storage with heated apples having higher and 1-MCP treated apples having lower activity than control apples (Fig. 2A). In the activity gels, two major and one minor isozyme were present (Fig. 3A). Heated apples showed higher APX activity in the low MW isozyme, while 1-MCP treated apples had the lowest level of activity throughout (Fig. 3A). CAT activity declined $\approx 50 \%$ during 16 weeks of storage in heated and 1-MCP treated apples (Fig. 2B). 1-MCP treated apples had the highest activity for the first 6 weeks of storage but decreased to similar levels in all three treatments. CAT activity in control fruit declined for the first 6 weeks. After reaching $50 \%$ of the initial value, CAT activity began to increase so that

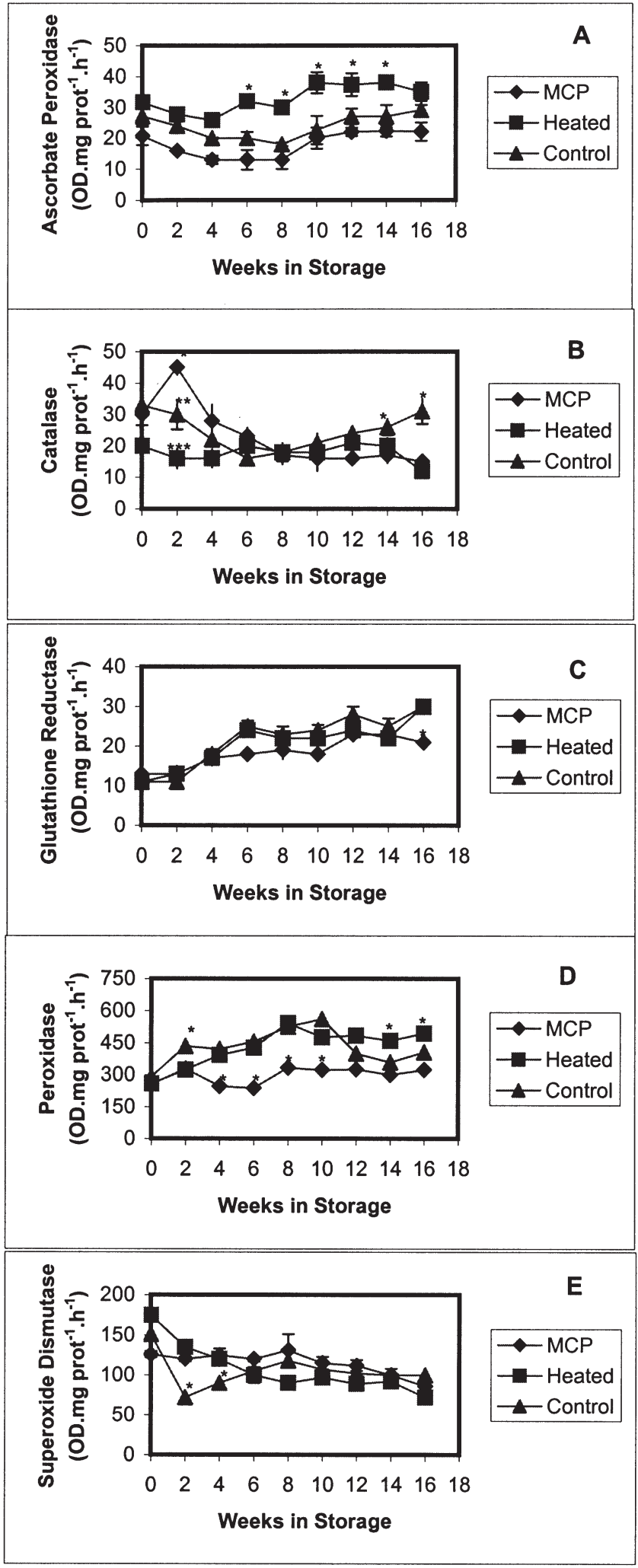

Fig. 2. Activites of five antioxidative enzymes in peel of 'Granny Smith' apples at harvest and at removal from $0{ }^{\circ} \mathrm{C}$ air storage at intervals of 2 weeks. Apples were either untreated (control), heated for $4 \mathrm{~d}$ at $38^{\circ} \mathrm{C}$ before storage, or treated for 16 h with $1 \mu \mathrm{L} \cdot \mathrm{L}^{-1} 1$-MCP. (A) Ascorbate peroxidase, (B) catalase, (C) glutathione reductase, (D) peroxidase, (E) superoxide dismutase. Standard deviation is shown and stars $(*)$ indicate a treatment that is significantly different from others at that observation time. 

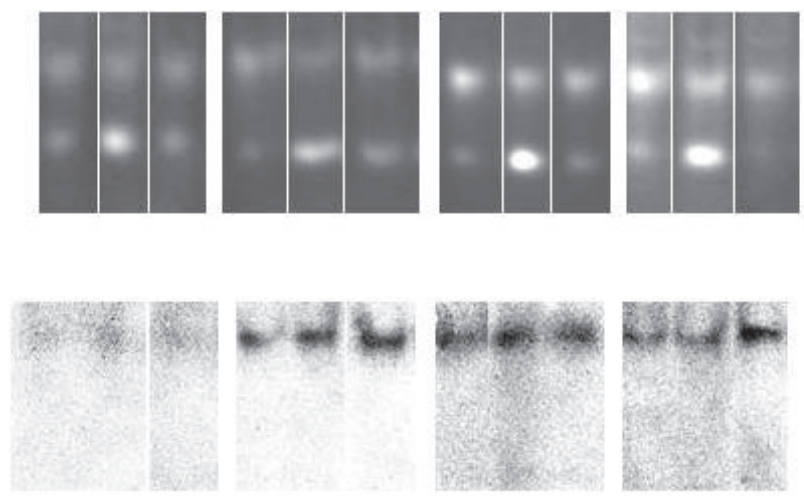

B
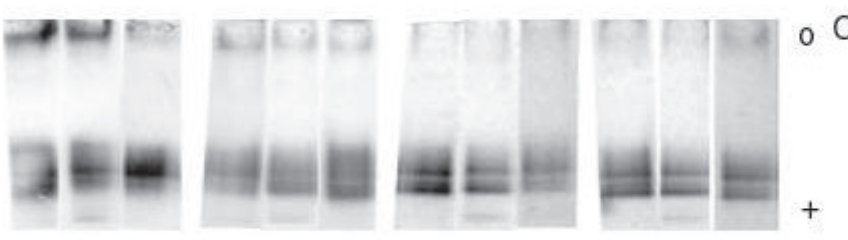

123

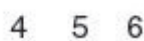

$\begin{array}{lll}7 & 8 & 9\end{array}$

$10 \quad 11 \quad 12$

Fig. 3. Activity gels of from peel extracts of 'Granny Smith' apples at removal from $0{ }^{\circ} \mathrm{C}$ air storage after $4,8,12$, and 16 weeks. Apples were either untreated (control) (lanes 1, 4, 7, 10) heated for $4 \mathrm{~d}$ at $38^{\circ} \mathrm{C}$ before storage (lanes 2, 5, 8, 11), or treated for $16 \mathrm{~h}$ with $1 \mu \mathrm{L} \cdot \mathrm{L}^{-1} 1-\mathrm{MCP}$ (lanes 3, 6, 9, 12). (A) Ascorbate peroxidase; $(\mathbf{B})$ glutathione reductase; $(\mathbf{C})$ peroxidase. In peroxidase $(\mathbf{C})$, the open circle indicates the cationic peroxidase bands which disappear as storage proceeds, while the + shows the extra acidic peroxidase band present in the heated fruit samples.

activities at harvest and after 16 weeks storage were similar $(\approx 30$ OD units $/ \mathrm{mg}$ protein/h), but at 6 weeks activity was only $50 \%$ of these rates. Heated apples had stable CAT activity throughout the storage period except for 16 weeks, when activity in both heated and 1-MCP treated fruit decreased. Activity gels showed one very high MW band with no differences amongst the treatments (data not shown).

GR activity increased 2- to 3-fold during storage, with no difference among the treatments (Fig. 2C). Isoenzyme bands were faint at 4 weeks of storage, but increased in intensity with longer storage with no visible differences amongst the treatments (Fig. 3B). POD activity increased during storage, with control and heated fruit showing a similar increase during the first 10 weeks. There was no change in activity of 1-MCP treated fruit (Fig. 2D). After 10 weeks of storage, activity in control apples peaked and began to decline, while activity in heated fruit remained stable. In the activity gels an additional low MW band was present in the heated fruit (Fig. 3C). On the other hand, isozymes of control fruit stained darker than heated or 1-MCP fruit extracts. There were basic isoforms present in the first weeks of storage and by 8 weeks these had almost disappeared. SOD activity decreased gradually as storage progressed (Fig. 2E). Seven bands were apparent in the activity gels with no differences amongst the treatments (data not shown).

AnTioxidant CONTENT. Free phenols were generally $\approx 70 \%$ of total phenols (Fig. 4A and B). The amounts fluctuated during the storage period, but did not show a trend to decrease or increase. Both types of phenols were higher in control apples at 6 weeks of storage and then decreased below the levels of heated and 1-MCP treated apples after 8 and 10 weeks. Thereafter, during weeks 12 to 16 phenol concentrations in apples of all three treatments were similar.
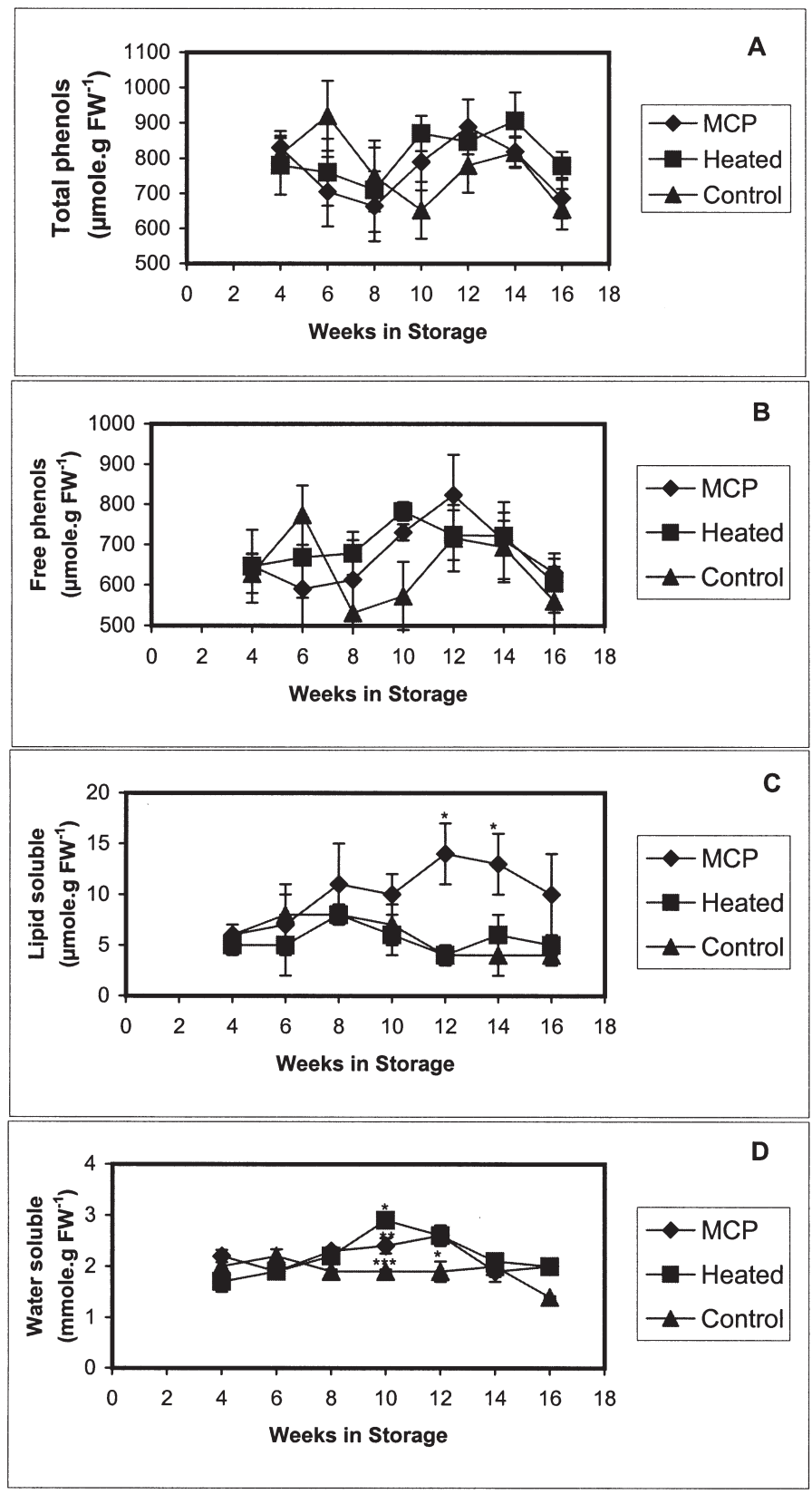

Fig. 4. Content of antioxidants in apple peel of 'Granny Smith' apples at removal from $0{ }^{\circ} \mathrm{C}$ air storage. Apples were either untreated (control), heated for $4 \mathrm{~d}$ at $38^{\circ} \mathrm{C}$ before storage, or treated for $16 \mathrm{~h}$ with $1 \mu \mathrm{L} \cdot \mathrm{L}^{-1} 1$-MCP. (A) Total phenols, (B) free phenols, (C) lipid soluble antioxidants, (D) water soluble antioxidants. Standard deviation is shown and stars $\left(^{*}\right)$ indicate a treatment that is significantly different from others at that observation time.

Lipid-soluble antioxidants were higher in 1-MCP treated apples (Fig. 4D). They increased between weeks 4 and 12 and declined thereafter. In heated and control apples, the levels were similar and stable during the 16 weeks of storage. Water-soluble antioxidants were similar in all treatments for the first 8 weeks of storage (Fig. 4D). Thereafter, they remained stable in control apples while increasing in heated and 1-MCP treated apples for weeks 10 and 12, after which they began to decline.

\section{Discussion}

Apples grown in warm climates are more susceptible to scald than those grown in temperate zones (Emonger et al., 1994; Ingle and D'Souza, 1989). It was found that, during apple maturation, 
temperatures below $10^{\circ} \mathrm{C}$ during the maturation period of apples could reduce the amount of scald, which developed in storage (Blanpied et al., 1991; Emonger et al., 1994). Mature apples left on the tree for longer periods, also showed reduced incidence of scald (Emonger et al., 1994). However, in Israel, late harvested 'Granny Smith' apples will show 100\% scald after 4 months in air storage (Lurie et al., 1990). In the present study, untreated control apples developed scald symptoms within 8 weeks of storage (Fig. 1A). Pre-storage heat treatments doubled the time that the apples were scald-free to 16 weeks, while 1-MCP treated apples showed no scald during the total storage time.

We have previously shown that heat treatment is effective against scald appearance for a period of up to 4 months in air storage, and at least 8 months in controlled atmosphere storage (Lurie et al., 1990). The delay in scald appearance was attributed to the inhibitory effects that heating has on many processes, including ethylene production, ripening, and volatile production (Fallik et al., 1997; Lurie and Klein, 1990). $\alpha$-Farnesene accumulation in peel tissue is also delayed by the heat treatment, as is the accumulation of its oxidation products (Fig 1).

1-MCP was a more potent inhibitor of scald than heat treatment. Similar response to 1-MCP has been shown for many different apple cultivars (Fan et al., 1999; Watkins et al., 2000). Because 1-MCP is an inhibitor of ethylene action in apples, it inhibits many ripening related processes along with the production of ethylene and volatiles (Fan and Mattheis, 1999; Lurie et al., 2002; Watkins et al., 2000). In this regard, the effect of $1-\mathrm{MCP}$ was similar to that of heat treatment, but the reduction of $\alpha$-farnesene accumulation was much greater than that resulting from heat treatment (Fig. $1 \mathrm{~B})$. Given the very low $\alpha$-farnesene content in 1-MCP treated apples there was almost no oxidation of the $\alpha$-farnesene.

This inhibitory effect of 1-MCP on $\alpha$-farnesene may obviate the need for the tissue to activate any anti-oxidative process. Heat treatment, on the other hand, has a smaller effect on the inhibition of $\alpha$-farnesene synthesis and its oxidation. Heat stress has also been found to enhance anti-oxidative processes in other systems, and by doing so, decreases chilling injury (Lurie et al., 1997; Sala and Lafuente, 1999, 2000). In the present study SOD activity was elevated at the beginning of storage and remained high in heat treated fruit for the first 6 weeks (Fig. 2E). Superoxide produced in different compartments of a plant cell is converted to hydrogen peroxide by SOD, thus converting one destructive active oxygen species to another slightly less destructive one. Hydrogen peroxide is reduced to water by either CAT or POD, of which APX is an important subfamily. APX was higher in heated than control fruit throughout the storage period (Fig. 2A), and POD showed an additional band in activity gels of heated fruit (Fig. 3). Therefore, it appeared that the heat treatment differentially affected some of the anti-oxidative enzymes in the apple peel and this might have helped decrease the rate of oxidation of $\alpha$-farnesene.

The activities of APX, GR and POD were lower in 1-MCP treated apples than in either control fruit or heated fruit. However, CAT activity in 1-MCP treated apples was higher than the other treatments after 2 and 4 weeks of storage, and SOD activity was higher than control fruit also after 2 and 4 weeks of storage (Fig. 2B and $\mathrm{E}$ ). These activities later decreased and were similar to those of control fruit. In general the activities of all five anti-oxidant enzymes were either stable or increased in all treatments during the 16 weeks of storage. Only SOD showed a decline during the storage period. These findings are in agreement with those of Du and Bramlage (1995) who examined CAT, POD and SOD activities in 'Cortland' apples during 24 weeks of storage. CAT and POD activities increased during storage while SOD activity decreased. The maintenance of antioxidant enzyme activity in general means that the onset of scald cannot be attributed to a major loss of the ability of the anti-oxidant enzymes to detoxify reactive oxygen species. Rather the changes in antioxidant enzyme activity were of a more subtle nature, and perhaps included the activities of particular isoenzymes, as differences were registered in isoenzymes of APX and POD (Fig. 3).

Phenol content in the apple peel did not appear to have any correlation to the development of scald or its prevention (Fig. 4A, B). These compounds have been investigated in the past and it was found that phenol concentration in apple peel differed significantly among cultivars, with 'Granny Smith' having the lowest concentration of phenols in all three cultivars examined (Golding et al., 2001). Peel phenol concentration generally increased at the beginning of storage and then remained constant or slowly declined. Ju and Bramlage (2000) found that late harvested 'Delicious' had more peel phenolics and this was negatively correlated with scald development. However, there was no decline in phenol concentration during storage as scald susceptibility increased.

1-MCP treated apples had high levels of lipid soluble antioxidants (Fig. 4 C). Callerani et al. (1990) found that lipid soluble antioxidants decreased during storage and that the activity was lower in scald affected tissue than in healthy peel from the same fruit. They also measured $\alpha$-tocopherol levels, which were 4 -fold higher in healthy fruit than in scalded fruit. Although levels of water soluble antioxidants were similar in apples from all treatments early in storage, both heated and 1-MCP treated fruit had higher levels of these antioxidants during the time that scald was developing in control apples. The major compounds in the category of water soluble antioxidants include ascorbic acid, glutathione, and phenols (Noctor and Foyer, 1998). Therefore, these compounds may also have a role to play in maintaining the ability of the apple peel to resist the development of scald.

In summary, determining the amount of antioxidant power in the peel tissue is a multifaceted process which can include total enzyme activity of various antioxidative enzymes, as well as the contribution made by the various isozymes of the enzymes. It also includes compounds with antioxidative activity, including those which act mostly in the cytosol and intercellular spaces as well as those that act in a lipid environment such as the membranes or the apple cuticle. In the present study, a simple direct relationship between antioxidant content and related enzyme activities to scald development was not found.

\section{Literature Cited}

Anderson, M.D., T.K. Prasad, and C.R. Stewart. 1995. Changes in isozyme profiles of catalase, peroxidase and glutathione reductase during acclimation to chilling in mesocotyls of maize seedlings. Plant Physiol. 109:1247-1257.

Anet, E.F.L.J. 1972a. Superficial scald, a functional disorder of stored apples. VIII. Volatile products from the autoxidation of $\alpha$-farnesene. J. Sci. Food Agr. 23:605-608.

Anet, E.F.L.J. 1972b. Superficial scald, a functional disorder of stored apples. IX. Effect of maturity and ventilation. J. Sci. Food. Agr. 23: 763-769.

Anet, E.F.L.J. 1974, Superficial scald, a functional disorder of stored apples. XI. Apple antioxidants. J. Sci. Food Agr. 25:299-304.

Blanpied, G.D., W.J. Bramlage, and C.L. Chu. 1991. A survey of the relationships among accumulated orchard house below $10^{\circ} \mathrm{C}$ and the incidence of storage scald on 'Starkrimson Delicious' apples. Can. J. Plant Sci. 71:605-608. 
Blanpied, S.M. and K. Silsby. 1992. Predicting harvest date windows for apples. Info. Bul. 221. Cornell Univ., Ithaca, N.Y.

Brand-Williams, W., M.E. Cuvelier, and C. Berset. 1995. Use of free radical method to evaluate antioxidant activity. Food Sci. Technol. (London) 28:25-30.

Callerani, G., G.C. Pratella, and R.A. Budini. 1990. The distribution and role of natural antioxidant substances in apple fruit affected by superficial scald. Adv. Hort. Sci. 3:144-146.

Du, Z. and W.J. Bramlage. 1994. Superoxide dismutase activities in senescing apple fruit (Malus domestica Burkh.). J. Food Sci. 59: 581-584.

Du, Z. and W.J. Bramlage. 1995. Peroxidative activity of apple peel in relation to development of poststorage disorders. HortScience 30: 205-209.

Emonger, V.E., D.P. Murr, and E.C. Lougheed. 1994. Preharvest factors that predispose apples to superficial scald. Postharvest Biol. Technol. 94:289-300.

Fallik, E., D.D. Archbold, T.R. Hamilton-Kemp, J.H. Loughrin, and R.W. Collins. 1997. Heat treatment temporarily inhibits aroma volatile compound emission from Golden Delicious apples. J. Agr. Food Chem. 45:4038-4041.

Fan, X. and J.P. Mattheis. 1999. Impact of 1-methylcyclopropene and methyl jasmonate on apple volatile production. J. Agr. Food Chem. 47:2847-2853.

Fan, X., S.M. Blankenship, and J.P. Mattheis., 1999. Development of superficial scald, soft scald, core flush and greasiness is reduced by MCP. J. Agr. Food Chem. 47:3063-3068.

Golding, J.B., W.B. McGlasson, S.G. Wyllie, and D.N. Leach. 2001. Fate of apple peel phenolics during cool storage. J. Agr. Food Chem. 49:2283-2289.

Huelin, F.E. and I.M. Coggiola. 1968. Superficial scald, a functional disorder of stored apples. IV. Effect of variety, maturity, oiled wraps and diphenylamine on the concentration of $\alpha$-farnesene in the fruit. J. Sci. Food Agr. 19:297-301.

Huelin, F.E. and I.M. Coggiola. 1970a. Superficial scald, a functional disorder of stored apples. V. Oxidation of $\alpha$-farnesene and its inhibition by diphenylamine. J. Sci. Food Agr. 21:44-48.

Huelin, F.E. and I.M. Coggiola. 1970b. Superficial scald, a functional disorder of stored apples. VII. Effect of applied $\alpha$-farnesene, temperature and diphenylamine on scald and the concentration and oxidation of $\alpha$-farnesene in the fruit. J. Sci. Food Agr. 21:584-589.

Huelin, F.E. and K.E. Murray. 1966. $\alpha$-Farnesene in the natural coating of apples. Nature 210:1260-1261.

Ingle, M. and M.C. D'Souza. 1989. Physiology and control of superficial scald of apples: A review. HortScience 24:28-31.

Ito, M., H. Kawaguch, Y. Sakota, J. Otonari, and H. Nitahara. 1993. Effects of polyphenols including flavonoids and glutathione reductase. Biosci. Biotechnol. Biochem. 57:1678-1680.
Ju, Z. and W.J. Bramlage. 2000. Cuticular phenolics and scald development in 'Delicious' apples. J. Amer. Soc. Hort. Sci. 125:498-504.

Lurie, S. and J.D. Klein. 1990. Heat treatment of apples: Differential effects on physiology and biochemistry. Physiol. Plant. 78:181-186.

Lurie, S., J.D. Klein, and R. Ben Arie. 1990. Prestorage heat treatment as a means to reduce superficial scald. J. Hort. Sci. 65:317-321.

Lurie, S., M. Laamim, Z. Lapsker, and E. Fallik. 1997. Heat treatments to decrease chilling injury in tomato fruit. Effects on lipids, pericarp lesions and fungal growth. Physiol. Plant. 100:297-302.

Lurie, S., C. Pre-Aymard, U. Ravid, O. Larkov, and E. Fallik. 2002. Effect of 1-methylcyclopropene on volatile emission and aroma in Anna apples. J. Agr. Food Chem. 50:4251-4256.

Meir, S. and W.J. Bramlage. 1988. Antioxidant activity in 'Cortland' apple peel and susceptibility to superficial scald after storage. J. Amer. Soc. Hort. Sci. 113:412-418

Meir, S., J. Kanner, B. Akiri, and S. Philosoph-Hadas. 1995. Determination and involvement of aqueous reducing compounds in oxidative defense systems of various senescing leaves. J. Agr. Food Chem. 43: 1813-1819.

Nocker, G. and C.H. Foyer. 1998. Ascorbate and glutathione. Annu. Rev. Plant Physiol. Plant Mol. Biol. 49:249-279.

Rao, M.V., G. Paliyath, and D.P. Ormrod. 1996. Ultraviolet-B- and ozoneinduced biochemical changes in antioxidant enzymes of Arabidopsis thaliana. Plant Physiol. 110:125-136.

Rao, M.V., C.B. Watkins, S.K. Brown, and N.F.Weeden. 1998. Active oxygen species metabolism in 'White Angel' $X$ 'Rome Beauty' apple selections resistant and susceptible to superficial scald. J. Amer. Soc. Hort. Sci. 123:299-304.

Sala J.M. and M.T. Lafuente. 1999. Catalase in the heat-induced chilling tolerance of cold-stored hybrid 'Fortune' mandarin fruits. J. Agr. Food Chem. 47:2410-2414.

Sala, J. M. and M.T. Lafuente. 2000. Catalase enzyme activity is related to tolerance of mandarin fruits to chilling. Postharvest Biol. and Technol. 20:81-89.

Shewfelt, R.L. and A.C. Purvis. 1995. Toward a comprehensive model for lipid peroxidation in plant tissue disorders. HortScience 30:213-218.

Vinson, J.A., X. Su, L. Zubik, and P. Bose. 2001. Phenol antioxidant quantity and quality in foods: Fruits. J. Agr. Food Chem. 49:5315-5321.

Watkins, C.B., W.J. Bramlage, and B.A. Cregoe. 1995. Superficial scald of 'Granny Smith' apples is expressed as a typical chilling injury. J. Amer. Soc. Hort. Sci. 120:88-94.

Watkins, C.B., J.F. Nock, and B.D. Whitaker. 2000. Responses of early, mid and late season apple cultivars to postharvest application of 1methylcyclopropene (1-MCP) under air and controlled atmosphere storage conditions. Postharvest Biol. Technol. 19:17-32.

Whitaker, B.D., T. Solomos, and D.J. Harrison. 1997. Quantification of $\alpha$-farnesene and its conjugated trienol oxidation products from apple peel by C18-HPLC with UV detection. J. Agr. Food Chem. 45:760-765. 